\title{
An Experimental Analysis of Investors' Pattern in Investment Decisions Making in Indian Stock Market
}

\author{
Sarika Keswani, Bharti Wadhwa
}

\begin{abstract}
The purpose of this paper is to see that how individuals are using their income in investing in stock market. How the interdependency exist between income and investment pattern. For achieving the objective, data was collected from 218 investors through self structured questionnaire to know the behavior of investors for using their deposable income. Chi square test was applied. It was found that interdependency exist between shares, postal savings, real estate, mutual fund, insurance and income groups. And there is no significant interdependency exist between income and investment pattern i.e. bank deposits, metal and PPF. Structured interview of 50 portfolio managers were taken to confirm and identify that which factors are influencing investors to invest their money and in which instrument. And it was found that the Investor's family structure and social environment, low risk, long term investment, the religious and political views, past investment experiences affect investors' investment decisions.
\end{abstract}

Keywords: Disposable Income, Investment, Investment Patterns, Income, Investors

\section{INTRODUCTION}

Disposable income means remaining income after paying all the taxes and social security charges that is available for expenses and savings. It is also known as disposable personal income (DPI). Disposable personal income is often monitored as one of the many key economic indicators used to gauge the overall state of the economy.

As it is an important economic indicator which may affect investment in stock market because if individuals have additional income then definitely they may use their additional income in investing in stock market. Disposable income definitely will affect stock market because whether any individual use his additional income to buy company products

If disposable income expands, families have more cash to either spare or spend, which leads to a growth in utilization. This expansion in consumption could increment corporate income and sales, increasing the

Revised Manuscript Received on July 22, 2019

Sarika Keswani, Research Scholar, School of Management, Symbiosis International University, Pune, (India) and Assistant Professor, Management, Gitarattan International Business School, Delhi, (India)

Bharti Wadhwa, Associate Professor, Symbiosis Centre for Management Studies, Noida, Symbiosis International University, Pune, (India) value of individual stocks. This expansion in individual share valuations could then prompt a market value. This potentially leads to an economic boom.

The inverse likewise remains constant. If disposable income decreases, households have less cash to spend and save, which at that point powers customers to expend less and become more frugal. This decrease in utilization could then decrease corporate sales and corporate profit, price decreasing the value of individual stocks. This reduction in individual share value valuations could then prompt a market-wide diminishing in value. This possibly prompts a depression or recession. Increments in disposable income don't generally result in an increase in value of the stock market and vice versa.

Please See Figure: 1 - How to calculate Disposable

Income:

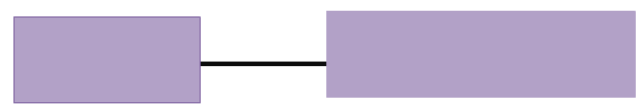

Figure 1

\section{RESEARCH QUeSTIONS}

Q.1. what is the concept of disposable income, what are the factors which affect disposable income?

Q.2 how investors of different income groups utilize disposable income in stock market? And its impact on stock returns in India.

Q.3 How much percentage of disposable income is invested in stock market via mutual fund, PPF, Insurance, FD, Savings accounts etc.

\section{The Relation Between Income Status AND the Pattern of InVestment}

Aim of this paper is to see the relation between income status and the pattern of Investment of an individual. Because if any individual has more income, then he may have more disposable income the he will be ready to invest more in stock market. If he can invest more in stock market, then what is the pattern of his of investment? And in which type of investment

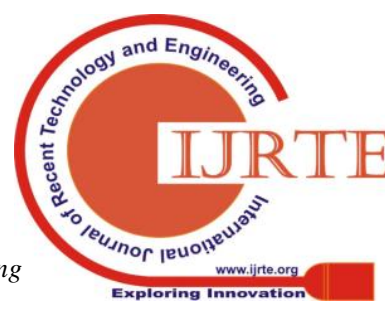


instrument he would like to invest his disposable income. It is assumed that if we have more disposable income then we can invest it more in any form of financial instrument for gaining more and more returns. So with the same object it was tried to find out the relationship between income status and pattern of investment and changing behavior of investors' whether it is positive or negative when there is any change in the govt. policies which affect income of the investors.

\section{RESEARCH OBJECTIVES}

The objectives of the present study are set as follows:

1. To know the concept of disposable income, how it occurs, how all the categories of investor utilize it?

2. How much percentage of disposable income is invested in stock market via mutual fund, PPF, Insurance, FD, Savings accounts etc.

3. To know the objectives of investors behind investing disposable income in stock market.

4. How the investors invest their disposable income in stock market ( help of fund managers or direct investment).

5. The study should reveal whether there exists any interdependency or relationship between income and investment pattern or they are independent to each.

\section{Literature ReVieW}

This is the new variable added in this study which has not been studied till now so limited related review is available:

In 1998, McCluer (1998) led a study based cross-sectional investigation of information gathered from the Michigan Survey of Consumers. Dissimilar to observational examinations that measure the degree to which spending reacts to the securities exchange, her investigation just studied whether individuals differed their ways of managing money dependent on changes in the stock exchange. McCluer presumed that a great many people varied their going through marginally as per the stock exchange. Furthermore, she found that families with high incomes invest more in stock market based spending changes. In spite of the fact that McCluer's investigation did not gauge the degree of the modification, her disclosure that high income investor's specialists responded more to the adjustments in the market infers that the marginal propensity to consume out of stock market wealth, for a given timespan, depends to some degree on the income of the average investor.

An examination by Mehra (2001) comparably inferred that individuals respond to changes in stock market wealth. His examination, in any case, comprised of a time series regression analysis, rather than a survey analysis. Mehra found that relationship between consumer spending and the stock market exchange was irrelevant in the short run, however generous over the long run. In spite of the fact that he found an immaterial short run relationship amid his investigation, Mehra recognized the tremendous size of the market prior to its most recent downturn (starting in late 2000) and anticipated a decrease in the normal $4 \%$ development rate of buyer spending as right on time as the primary quarter of 2001 .

Ludvigson and Steindel (1999) investigated the impact of total wealth on buyer consumptions somewhere in the range of 1953 and 1997. Notwithstanding their underlying 43-year time range, Ludvigson and Steindel additionally performed similar regression analyses on six sub-sets of time inside the 1953 to 1997 period. They evaluated a scope of marginal propensities to expend out of all total wealth changing from a high of .106 (the period from1976-1985) and a low of .021 (from 1986-1997). Ludvigson and Steindel's first investigation used a variable representing total wealth. This variable included stock exchange wealth along with other household wealth.

\section{ReSEARCH Methodology}

\section{Research Design}

For this study, a survey and an interview were conducted to know the behavior and the patterns of investors in making investment decisions in the stock market.

\section{Population of the Study and data collection}

Study is divided in two parts. In First part only data was collected through self-structured questionnaire from investors and in second part data was collected through interview of portfolio managers.

\section{Part I:}

For collecting primary data researcher used survey and interview method. Data of 268 investors were taken for analysis, either they are investing their disposable income in stock market or not. And even to know their interdependency between income and investment patterns.

\section{Part II:}

Interview was also conducted from the portfolio managers to know the behavior of the investors while choosing investment pattern. 50 portfolio managers were interviewed; those were dealing with investments and investors.

\section{Data Analysis}

The data collected was analyzed using quantitatively using inferential statistics using SPSS 22. Several inferential statistical models were used to draw conclusions. 


\section{Analytical Models}

Chi square test for check the interdependency between income and investment pattern and pie chart for representing responses of portfolio managers regarding behavior of investors while making investment decisions. Data was analyzed at $5 \%$ significance level.

\section{Data and Methodology}

Dependent variable Disposable income

Independent Variable: Investment patterns

\section{Analysis and Interpretation:}

A: Analysis of questionnaire related to investment behavior regarding Disposable Income

Q.No. 1 Are you an income tax payee?

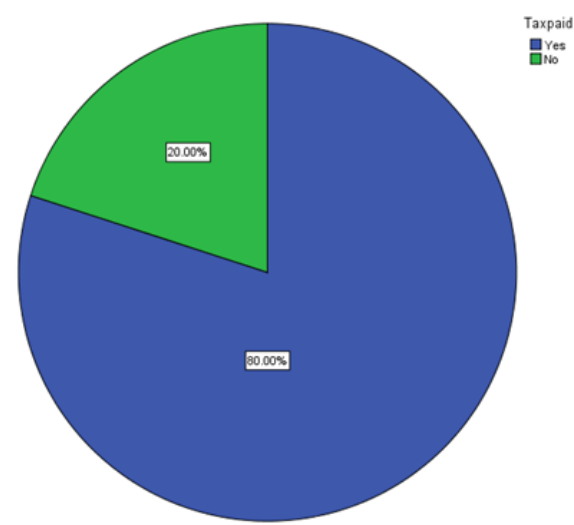

Analysis

$80 \%$ respondents are tax payers and rest $20 \%$ respondents do not pay tax due to low income level.

\section{Q. No 2}

H1: There is a significant interdependency exist between income and investment pattern

Exhibit

\begin{tabular}{|l|l|l|l|}
\hline Variable 1 & Variable 2 & $\chi 2$ & Sig (P) \\
\hline Income & Saving Bank Deposits & 0.406 & 0.816 \\
\hline Income & Fixed Deposits & 0.320 & 0.852 \\
\hline Income & Shares & 78.391 & 0.000 \\
\hline Income & Metal & 1.782 & 0.411 \\
\hline Income & Postal Savings & 68.459 & 0.000 \\
\hline Income & Real Estate & 71.391 & 0.000 \\
\hline Income & Mutual Fund & 49.254 & 0.000 \\
\hline Income & Insurance & 46.855 & 0.021 \\
\hline Income & PPF & 0.054 & 0.974 \\
\hline
\end{tabular}

H1a: There is a significant interdependency exist between income and investment in Saving Bank Deposits

The result $(\chi 2=0.406, \mathrm{df}=2, \mathrm{P}=0.816)$ suggest that there is no independency exist between income group and investment in saving bank deposits, also no. of representation in contingency table (Exhibit) suggest that rich class is more interested in investing in Saving Bank Deposits.

H1b: There is a significant interdependency exist between income and investment in Fixed Deposits

The result $(\chi 2=0.320, \mathrm{df}=2, \mathrm{P}=0.852)$ suggest that there is no an independency exist between income group and investment in Fixed Deposits, also no. of representation in contingency table (Exhibit) suggest that rich class is more interested in investing in Fixed Deposits.

H1c: There is a significant interdependency exist between income and investment in Shares

The result $(\chi 2=0.78 .391, \mathrm{df}=2, \mathrm{P}=0.000)$ suggest that there is an independency exist between income group and investment in Shares, also no. of representation in contingency table (Exhibit) suggest that rich class is more interested in investing in Share market.

H1d: There is a significant interdependency exist between income and investment in Metal

The result $(\chi 2=1.782, \mathrm{df}=2, \mathrm{P}=0.411)$ suggest that there is no independency exist between income group and investment in metal, also no. of representation in contingency table (Exhibit) suggest that rich class is more interested in investing in metal like gold and silver.

H1e: There is a significant interdependency exist between income and investment in Postal savings.

The result $(\chi 2=68.459, \mathrm{df}=2, \mathrm{P}=0.000)$ suggest that there is an independency exist between income group and investment in postal, also no. of representation in contingency table (Exhibit) suggest that poor and rich class are more interested in investing in postal savings.

H1f: There is a significant interdependency exist between income and investment in Real Estate.

The result $(\chi 2=0.71 .391, \mathrm{df}=2, \mathrm{P}=0.000)$ suggest that there is an independency exist between income group and investment in Real Estate, also no. of representation in contingency 
table (Exhibit) suggest that rich class is more interested in investing in real estate sector.

H1g: There is a significant interdependency exist between income and investment in Mutual Fund.

The result $(\chi 2=49.254, \mathrm{df}=2, \mathrm{P}=0.000)$ suggest that there is an independency exist between income group and investment in Mutual Fund, also no. of representation in contingency table (Exhibit) suggest that middle and rich class are more interested in investing in mutual funds. Whereas poor income group people tend to avoid investing in Mutual fund.

H1h: There is a significant interdependency exist between income and investment in Insurance.

The result $(\chi 2=46.855, \mathrm{df}=2, \mathrm{P}=0.021)$ suggest that there is an independency exist between income group and investment in Insurance, also no. of representation in contingency table (Exhibit) suggest that middle and rich class are more interested in investing in insurance sector.

H1i: There is a significant interdependency exist between income and investment in PPF

The result $(\chi 2=0.054, \mathrm{df}=2, \mathrm{P}=0.974)$ suggest that there is an independency exist between income group and investment in PPF, also no. of representation in contingency table (Exhibit) suggest that middle and rich class are more interested in investing in insurance sector.

Q.No. 3 What is the percentage of savings from your total income?

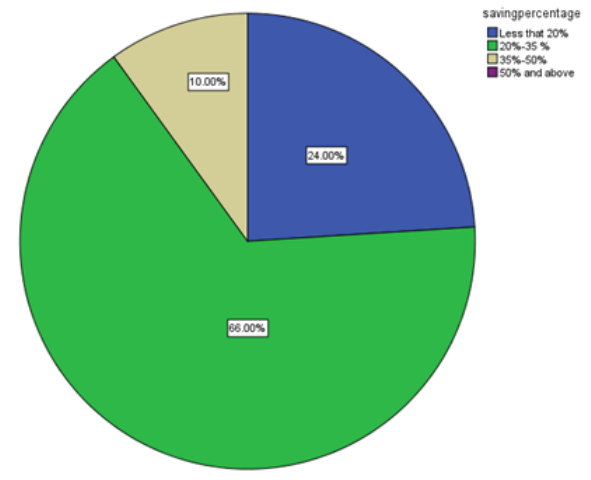

Interpretation

$66 \%$ people save $20-35 \%, 10 \%$ people save $35-50 \%$, $24 \%$ people save upto $20 \%$ and no people saves more than $50 \%$ of their total income. That means the many people are able to save $20-35 \%$ of their income very easily.

Q.No 4 What are the factors to which you give priority when you invest?

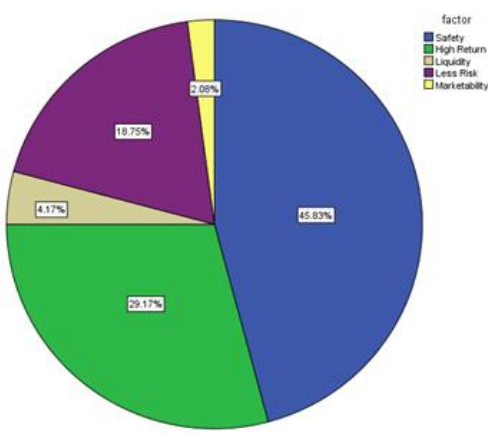

Analysis

$45.83 \%$ investors give priority to safety, $29.17 \%$ to high returns, $4.17 \%$ to liquidity, $18.75 \%$ less risk and $2.06 \%$ to marketability. That shows that safety is the priority for the investors and it is important at the time of making investment decisions. Because many middle class persons prefer the safety funds rather than risky.

Q.No 5 You invest in the financial instruments / securities which give:-

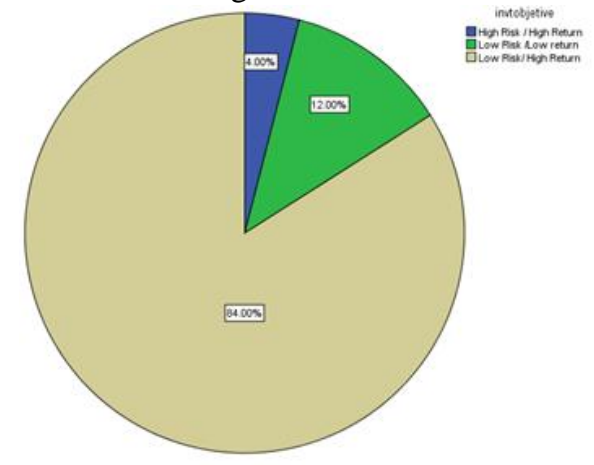

Analysis

$84.00 \%$ investors have objectives of low risk/high returns, $4 \%$ high risk/high returns and $12 \%$ low risk/low returns. That shows that investors in India do not want to take more risk their major objective is to get more returns in less risk. Because many investors do not want to take high risk and do not consider stock market.

Q.No. 6 Changes in Government policies (contributions, tax reductions etc.) affect your behavior in.

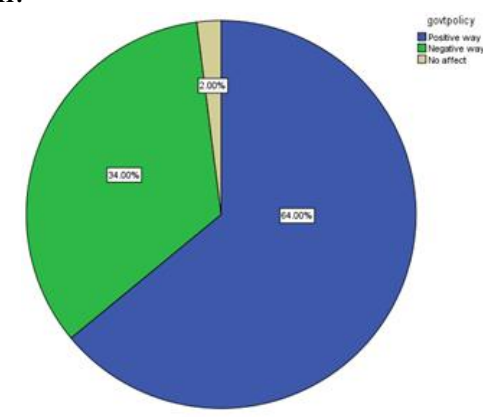

Interpretation

$64 \%$ are agree on that changes in Government policies (contributions, tax reductions etc.) affect your

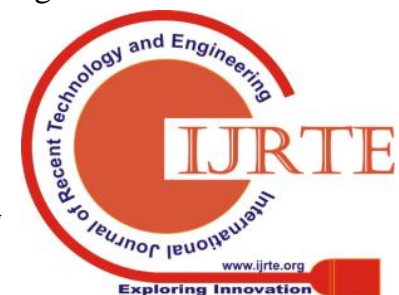


behavior in positive behavior but $34 \%$ are not in this favor because their behavior will be change in negative way and only $2 \%$ agreed on that there will not be any effect in their behavior.

That means if Govt. reduces the tax amount then people have more income to save or will have more disposable income so they can invest this in share market or in any other option.

Q. No. 7 Increase in income level raises your interest on financial instruments in........

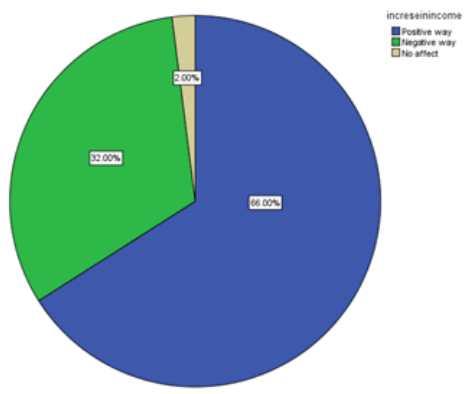

$66 \%$ agreed that if there is any increase in their income level then their interest on financial instruments in positive way and interest of $32 \%$ will change in a negative way and $2 \%$ are not agree with that their behavior will remain same they will invest the same.

If the income level is increasing then they will invest more because they have more disposable income.

Q No.8 When contemplating your investments, do you think you have?

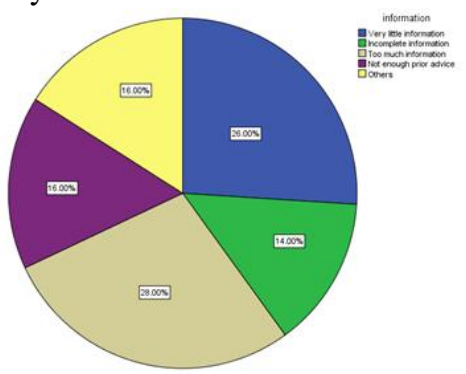

Analysis

$26 \%$ investors have very little information at the time of considering any instrument for the investment purpose, $14 \%$ have incomplete information, $28 \%$ have too much information, $16 \%$ not enough and $16 \%$ take prior advice from others. It shows that many investors have information related to investment.

$26 \%$ investors have little information because many people do not consider stock market as a safe fund.

Q.No 9 How do you manage your investments?

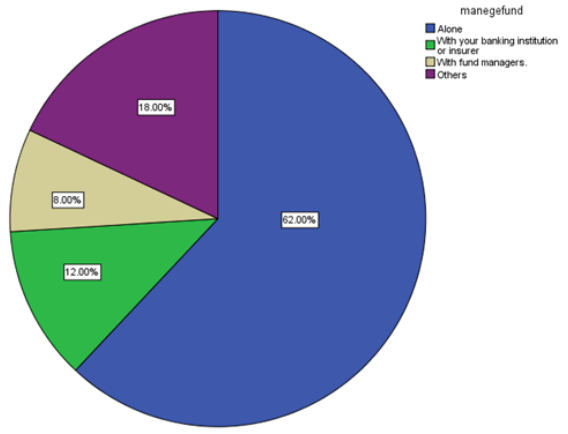

Analysis

$62 \%$ investors manage their funds alone, $12 \%$ through the banking institutions or insurer, $8 \%$ through the fund managers and $18 \%$ investors take the help of others or mange through the different sources. It shows that the major part of investment is done by the individual investors by their own.

Still in India people are not focusing on wealth creation they invest just for using their disposable income and still there is a lack of serious thinking behind their investment decisions.

Q.No 10 According to you, which one do you rate as the best investment instrument?

$9.70 \%$ to savings bank, $22.76 \%$ to fixed deposits, $25.37 \%$ to shares/debentures, $7.46 \%$ to metal, $1.12 \%$ to postal savings, $24.63 \%$ to real estate, $1.49 \%$ to insurance and $7.46 \%$ to others investors consider to savings bank the best investment instrument. It shows that the according to investors fixed deposits, share and debentures and real estate are the best investment instrument for investment purpose.

Most of the investors are conservative in nature that is why they think that real estate and fixed deposits are the risk free, safe and high return securities. While young generation investors invest in shares and debentures because they want high return that is why they invest in stock market.

\section{B: Analysis of Interview of portfolio managers:}

\section{A. Age of clients?}

The age of clients who are investing in stock market are $44 \%$ of the age of 21 to 30 years, $40 \%$ of the age of 31 to 40 years and $16 \%$ of the age of 41 to 50 years. That shows that young and middle generation is more interested in investing in stock market. But as people are getting older that do not like to invest money anywhere because they do not want to take risk. 


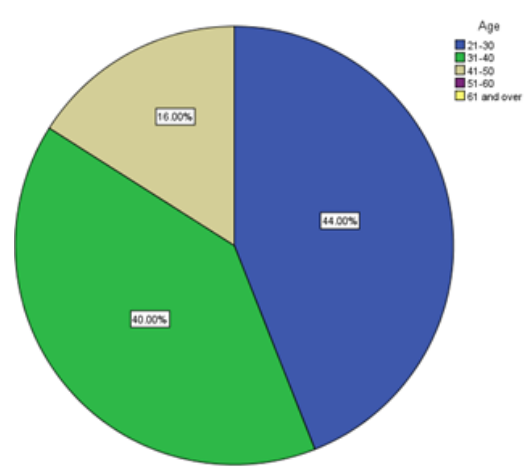

Client's profession whom you deal mostly?

Mostly businessmen invest in stock market. Salaried person invest in stock market but the percentage is less as compared to businessman.

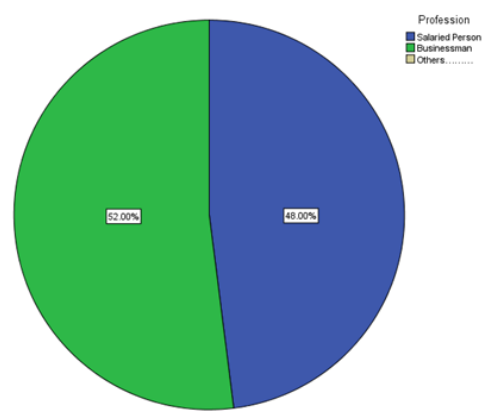

How much do they spend in their investments from their total income?

This analysis indicates that people spend in investment from their total income as $24 \%$ invest up to $20 \%, 24 \%$ people invest $20-35 \%, 10 \%$ people invest $35-50 \%$ and no individual spend their income $50 \%$ and more.

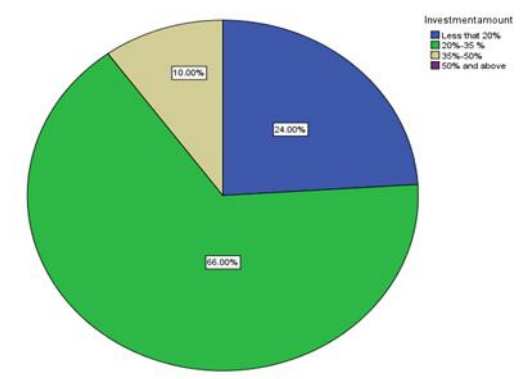

Risk appetite (Risk bearing capacity of clients)

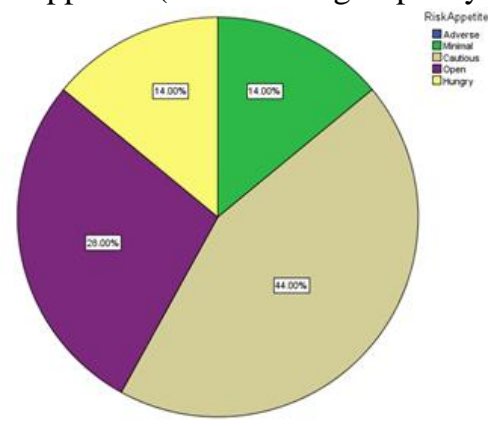

\begin{tabular}{|l|l|}
\hline Risk Type & $\%$ of Risk appetite (Risk bearing capacity of clients) \\
\hline Adverse & $0 \%$ \\
\hline Minimal & $14 \%$ \\
\hline Cautious & $44 \%$ \\
\hline Open & $28 \%$ \\
\hline Hungry & $14 \%$ \\
\hline
\end{tabular}

Questions

1 How much does the investor's family structure and social environment affect the investment decision of the investor?

$82 \%$ The family structure and the social environment of the investor influence the investment decisions of the investor because the investment of the investor will depend on the size of the family and the environment. If they have a small family and a good income, then they may have less expenses than the large family, so they naturally have more savings to invest or vice versa. $18 \%$ answered that the family structure and the social environment do not influence the investment decision, which is much lower.

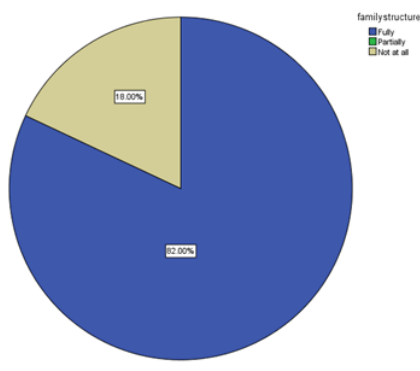

1 Investors tend to prefer low risk investments as they get old.

$64 \%$ are agreed with this that they tend to prefer low risk investment as they get old because only young generation is ready to take high risk because as they grow the responsibility of them is also increasing so with that they are not able to take more risk. And 36\% are not agree with this they are ready to take risk in old age also.

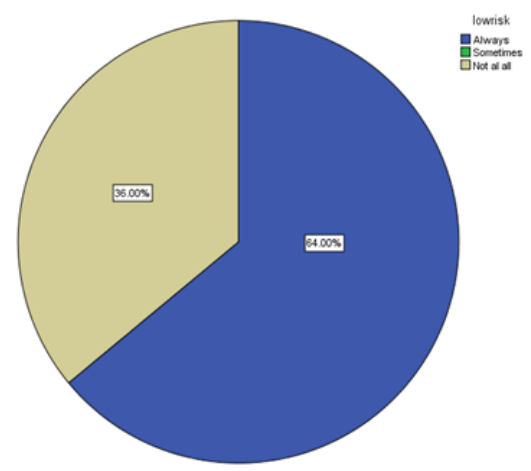

2 Investors prefer long term investments rather than short term investments

$78 \%$ investor prefer long term investment because they think in long term investment plans they get more returns, because there are some schemes and securities that 
gives maximum return only in case we hold it for the long term. $16 \%$ investors are not totally disagree with this and $6 \%$ investors feels sometimes it happens and sometimes not.

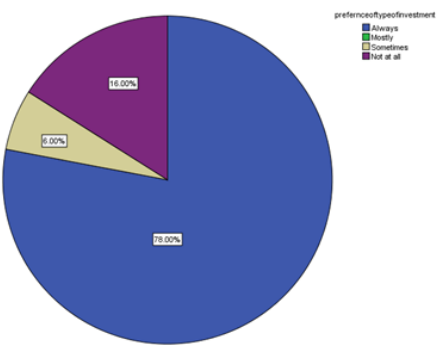

4. Investors closely follow investment tools' performance of return.

64\% investors closely follow investment tools; performance of return that shows that they are aware about the tools and techniques to measure performance of return with the help of portfolio managers. If there are aware that mean they will be able to right decision for their plans but still $36 \%$ investors are not aware so govt or financial institutions need to promote awareness programs for that.

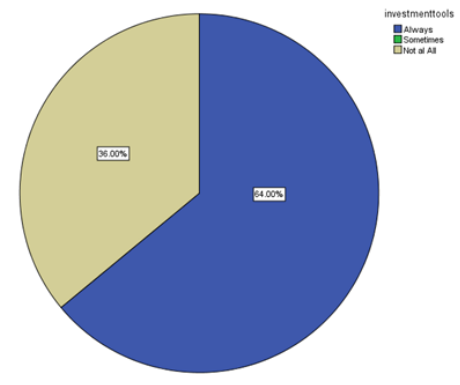

5. Are Investors having sufficient information regarding investment tools?

$40 \%$ investors have very little information regarding investment tools and $18 \%$ have incomplete information that means they need awareness about investment tools so that they can take right decisions and $30 \%$ have too much information with that they can take right decision and $12 \%$ investors have not enough information they take decision after taking advice of experts.

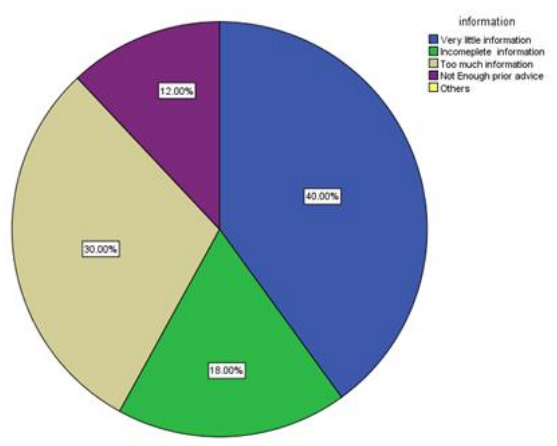

6. How much level of self confidence is there in investor's investment decisions?

$60 \%$ investors are very confident about their investment decisions and $40 \%$ are not confident that they have taken correct decision because they are not fully aware about the investment tools.

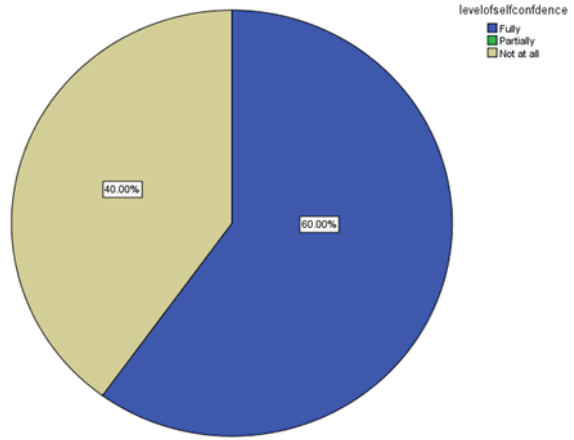

7. Do Investors discriminate between domestic and foreign companies in their investment preference?

$76 \%$ Investors are able to discriminate between domestic and foreign companies in their investment preference and still $24 \%$ are not able to discriminate between domestic and foreign companies in their investment preference.

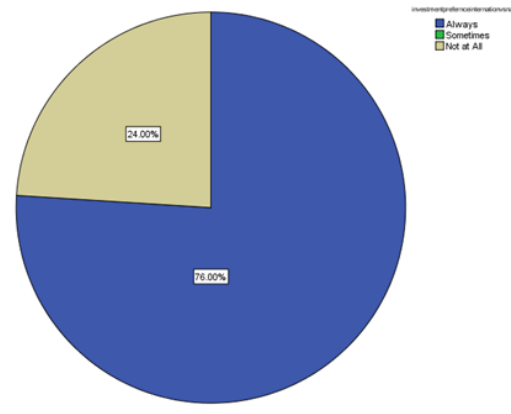

8. Investors' religious and political views affect their investment decisions

$60 \%$ investors are not agreed with that, that the religious and political views affect their investment decision they are not influenced by that. $34 \%$ investors are agreed that they are influenced by religious and political views and $6 \%$ investors rarely influenced by religious and political views.

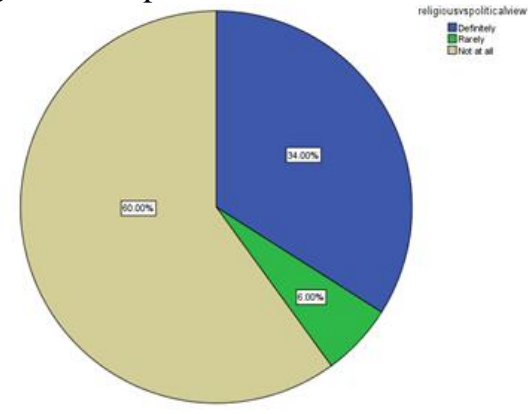

9. Investors prefer less risky investment tools (bank deposit, bond, etc.) to high risky investment tools (stock certificate, etc.)

$60 \%$ investors prefer less risky investment tools to high risky that are why they prefer to invest in bank deposits and bonds etc. But $40 \%$ are ready to take high risk that is why they prefer to invest in share and certificates etc. 


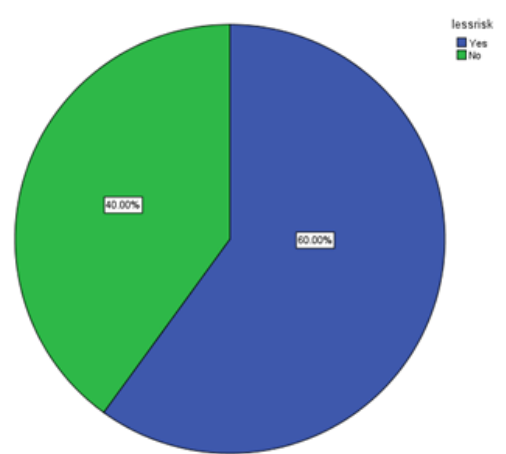

10. Investors tend to reduce risk through portfolio diversification

$80 \%$ investors tend to reduce risk through portfolio diversification and $18 \%$ investors do not tend and $2 \%$ investors rarely tend to reduce risk through portfolio diversification.

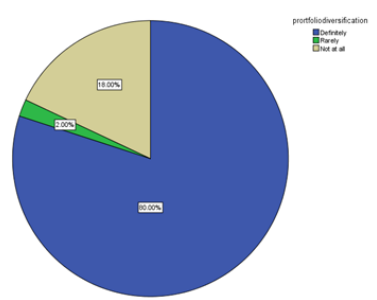

11. Changes in Government policies (contributions, tax reductions etc.) affect investors' behavior in.

$64 \%$ investors think that changes in Govt policies like contributions, tax reductions etc will affect their behavior in positive way because if they have to pay less tax then they will have more disposable income then they can invest that savings in share market or any other securities. $34 \%$ are negative about that and $2 \%$ investors have no effect of changed on Govt. policies.

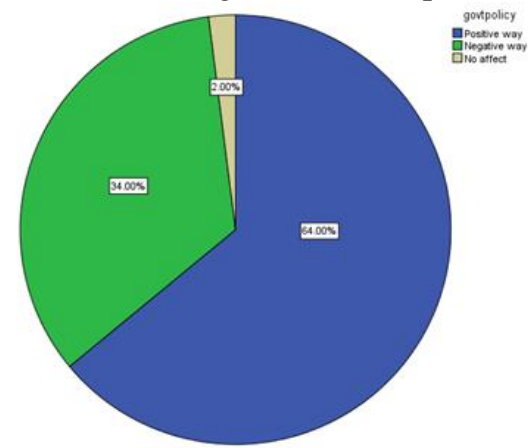

12. Increase in income level raises investors' interest on financial instruments in........

$66 \%$ investors think that Increase in income level raises will change their interest on financial instruments in positive way and $32 \%$ think it will effect in negative way and only $2 \%$ think that there will be no changes.

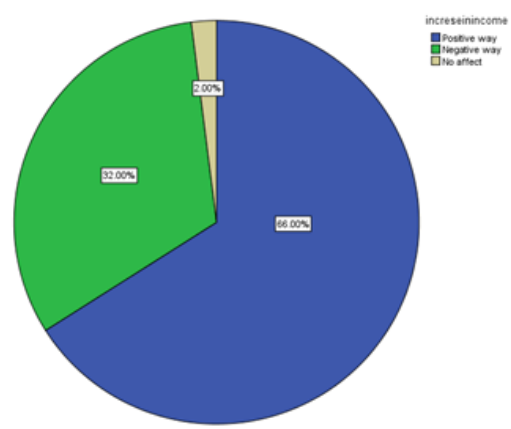

13. Investors consider their past investment experiences while taking investment decisions

96\% investors consider their past investment experiences while taking investment decisions and only $4 \%$ investors do not consider their past investment experiences while taking investment decisions. That mean past experience is very important to take investment decision.

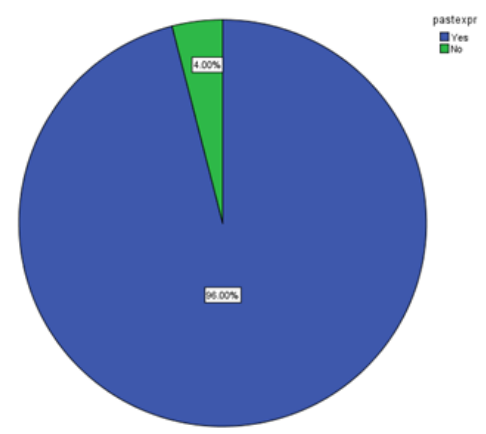

14. Investors are influenced by expert (consumer or investment representatives) and other investors' decisions while taking investment decisions

94\% investors are influenced by expert (consumer or investment representatives) and other investors' decisions while taking investment decisions and 6\% Investors are not influenced by expert (consumer or investment representatives) and other investors' decisions while taking investment decisions. Because lack of the awareness they take opinion from the expert. 


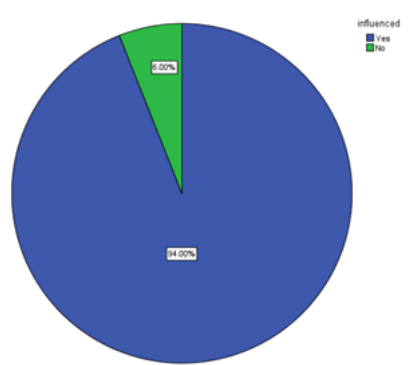

15. In which type of security and instrument investors want to invest their savings?

$70 \%$ investors like to choose low risk and high return security, 22\% low risk and low return and only $6 \%$ choose high risk and high return because still in India investors are not ready to take high risk.

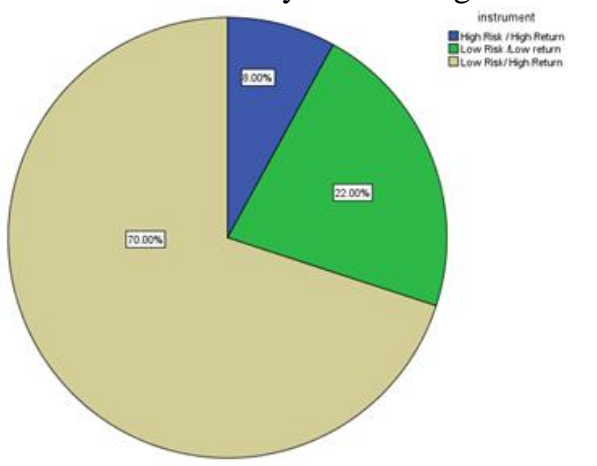

16. What is the factor to which investor give priority most?

$36 \%$ give less risk to priority most, $28 \%$ give high return to priority most, $24 \%$ give safety to priority most, $10 \%$ give liquidity to priority most and $2 \%$ give marketability to priority most. That shows that investors are not ready to take high risk they want to earn more profit in less risk.

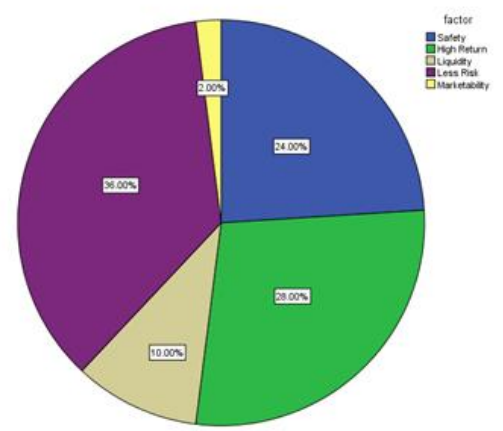

17. Where do investors invest their savings most (Investors preference)?

$26 \%$ investors invest their savings in PPF, 24\% investors invest their savings in share and debentures, $16 \%$ investors invest their savings in Real Estate, 14\% investors invest their savings in Fixed Deposits, 6\% investors invest their savings in Postal savings, 6\% investors invest their savings in saving bank, 4\% investors invest their savings in Gold and Silver and 4\% investors invest their savings in Insurance.

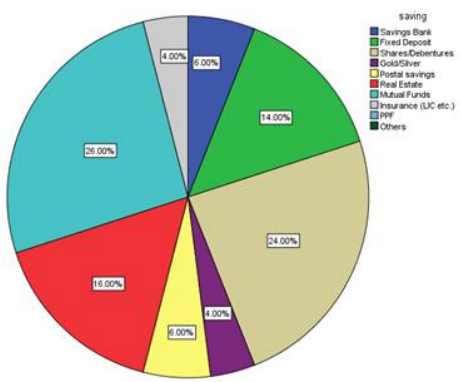

18. According to investors, which one is the best investment instrument?

$34 \%$ think that Fixed deposit is the best investment instrument, $26 \%$ think that shares and debentures are the best investment instrument, $14 \%$ think that real estate is the best investment instrument, $10 \%$ think that saving bank deposit is the best investment instrument, $6 \%$ think that insurance is the best investment instrument, $4 \%$ think that postal saving is the best investment instrument, $2 \%$ think that gold and silver are the best investment instrument and rest $4 \%$ think that other is the best investment instrument.

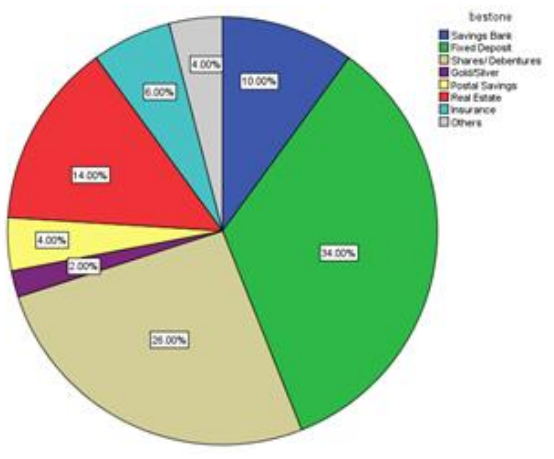

\section{V FINDINGS}

By survey of investors, it was found that interdependency exist between shares, postal savings, real estate, mutual fund, insurance and income groups. And there is no significant interdependency exist between income and investment pattern i.e. savings bank deposits, fixed deposits, metal and PPF.

- In case of portfolio managers' interview found that the Investor' s family structure and social environment, low risk, long term investment, the religious and political views, past investment experiences affect investors' investment decisions. Maximum investors are not aware about investment tools and schemes.

- Now-a-days investors are investing money in portfolio to diversity risk. Changes in Government policies (contributions, tax reductions etc.) affect investors' behavior in positive way because they need to pay less taxes so they will have more savings then they can use this money for investments. According to portfolio managers maximum investors like to invest money in PPF and fixed deposits. 


\section{CONCLUSION AND RECOMMENDATIONS}

Through in this study it was tried to perform necessary analyses to answer the research question. For the primary data was collected to measure the interdependency exist between income and investment pattern. To see is there any interdependency exist between income and investment pattern or not. For that data of 218 investors were collected through self structured questionnaire and it was found that interdependency exist between shares, postal savings, real estate, mutual fund, insurance and income groups. And there is no significant interdependency exist between income and investment pattern i.e. savings bank deposits, fixed deposits, metal and PPF.

After that in the II step data was collected through structured interview of 50 portfolio managers to confirm and identify that which factors are influencing investors to invest their money and in which instrument. And it was found that the Investor's family structure and social environment, low risk, long term investment, the religious and political views, past investment experiences affect investors' investment decisions. Maximum investors are not aware about investment tools and schemes. Now-a-days investors are investing money in portfolio to diversity risk. Changes in Government policies (contributions, tax reductions etc.) affect investors' behavior in positive way because they need to pay less taxes so they will have more savings then they can use this money for investments. According to portfolio managers maximum investors like to invest money in PPF and fixed deposits.

\section{REFERENCES}

1. Ando, A., \& Modigliani, F. (1963). The "life cycle" hypothesis of saving: Aggregate implications and tests. The American economic review, 53(1), 55-84.

2. Badrinath, S.G., and Wilbur, G. Lewellen. (1991). "Evidence on Tax Motivated Securities Trading Behavior," Journal of Finance, 46, 369-383.

3. Benartzi, Shlomo, and Richard H. Thaler. (1995) "Myopic Loss Aversion and the Equity Premium Puzzle," Quarterly Journal of Economics, 110, 75-92.

4. Benartzi, Shlomo, and Richard H. Thaler. (1999). "Risk Aversion or Myopia: The Fallacy of Small Numbers and Its Implications for Retirement Savings," Management Science, 45, 364-381.

5. Ben-Horin, Moshe. (1996). Securities and the Capital Market, Tel Aviv, Tcherikover Publishers, (In Hebrew).

6. Constantinides, George, M., (1983). "Capital Market Equilibrium with Personal Tax," Econometrica, 51, 611 636.

7. Constantinides, George, M. (1984). "Optimal Stock Trading with Personal Taxes," Journal of Finance, 13, 65-89.

8. Ferris, Stephen, P., Haugen, Robert, A., and Anil K. Makhija. (1988). "Predicting Contemporary Volume with Historic Volume at Differential Price Levels: Evidence Supporting the Disposition Effect," Journal of Finance, 43, 677-697.

9. Genesove, David, and Christopher J. Mayer. (1999). "Loss Aversion and Seller Behavior: Evidence from the Housing Market", Working paper, Department of Economics, The Hebrew University, Jerusalem.

10. Grinblatt, M., \& Keloharju, M. (2000). The investment behavior and performance of various investor types: a study of Finland's unique data set. Journal of financial economics, 55(1), 43-67.

11. Heath, Chip, Steven Huddart, and Mark Lang, (1999). "Psychological Factors and Stock Options Exercises", Forthcoming in the Quarterly Journal of Economics.
12. Kahneman, Daniel and Amos Tversky. (1979). " Prospect Theory: An Analysis of Decision Under Risk", Econometrica, 46, 171-185.

13. Kahneman, Daniel and Amos Tversky. (1984). "Choices Values and Frames," American Psychologist, 39, 341-50.

14. Kalpagam, U. (1994). Labour and gender: Survival in urban India. SAGE Publications Pvt. Limited.

15. Lettau, M., and S. C. Ludvigson (2001a): "Consumption, Aggregate Wealth and Expected Stock Returns," Journal of Finance, 56(3), 815-849.

16. Lewellen, W. G., Lease, R. C., \& Schlarbaum, G. G. (1977). Patterns of investment strategy and behavior among individual investors. The Journal of Business, 50(3), 296-333.

17. Lease, Ronald C., Lewellen, Wilbur G., and Gary G. Schlarbaum. (1974). "The Individual Investor: Attributes and Attitudes", Journal of Finance, 29, 413-433.

18. Levhari, David, and Haim Levy. (1977). "The Capital Asset Pricing Model and the Investment Horizon", Review of Economics and Statistics, 59, 92-104.

19. Levy, Haim, Moshe Smith and Marshall Sarnat. (1980). The Stock Exchange, Tel Aviv, Israel: Schocken Publishing. (In Hebrew)

20. Luffy, R., \& Grove, S. K. (2003). Examining the validity, reliability, and preference of three pediatric pain measurement tools in African-American children. Pediatric nursing, 29(1), 54.

21. Martha Starr-McCluer (1994). "Changes in Family Finances from 1989 to 1992: Evidence from the Survey of Consumer Finances," Federal Reserve Bulletin, Vol. 80 (October), pp. 861-882.

22. Martha Starr-McCluer (1994). "Changes in Family Finances from 1989 to 1992: Evidence from the Survey of Consumer Finances," Federal Reserve Bulletin, Vol. 80 (October), pp. 861-882.

23. Ngoc, L. T. B. (2014). Behavior pattern of individual investors in stock market. International Journal of Business and Management, 9(1), 1.

24. Schlarbaum, Gary, G., Lewellen, Wilbur, G., and Ronald C. Lease. (1978a). "Realized Returns on Common Stock Investments: The Experience of Individual Investors", Journal of Business, 51, 299-325.

25. Shapira, Z., \& Venezia, I. (2001). Patterns of behavior of professionally managed and independent investors. Journal of Banking \& Finance, 25(8), 1573-1587.

26. Sharpe, William E. and Gordon J. Alexander. (1990).Investments. Englewood Cliffs, NJ. Prentice Hall International.

27. Shleifer, Andrei, and Robert W. Vishny. (1990). "Equilibrium Short Horizons of Investors and Firms," American Economic Review, Papers and Proceedings, 80,148-152.

28. taw, Barry. (1997). "The Escalation of Commitment: An Update and Appraisal." In Z. Shapira (ed.) Organizational decision making. New York: Cambridge University Press.

29. Tse, R. Y., \& Raftery, J. (1999). Income elasticity of housing consumption in Hong Kong: a cointegration approach. Journal of Property Research, 16(2), 123-138.

\section{AUTHORS PROFILE}

Sarika Keswani, Research Scholar, School of Management, Symbiosis International University, Pune, (India) and Assistant Professor, Management, Gitarattan International Business School, Delhi, (India).

Bharti Wadhwa, Associate Professor, Symbiosis Centre for Management Studies, Noida, Symbiosis International University, Pune, (India). 